\title{
Metastasis in penile corpus cavernosum from esophageal squamous carcinoma after curative resection: a case report
}

\author{
Lingmin Song $^{1 *}$, Yangmin Wang ${ }^{2}$ and Guobin Weng
}

\begin{abstract}
Background: Metastasis in penile corpus cavernosum from esophageal squamous carcinoma is a rare but fatal disease, which was reported in cases without series studies.

Case presentation: An 84-year-old male smoker, who had a history of curative resection of esophageal squamous carcinoma 12 months before, presented with aggressive dysuria and penis pain for 1 month. Ultrasonic guided biopsy diagnosed metastatic squamous carcinoma from the primary in the esophagus. The accurately modulated conformal radiotherapy and non-steroidal antiinflammatory drugs achieved to alleviate the penis pain temporarily. But the disease progressed and disseminated in a short period. He died of multiple metastases and cancer cachexia in 4 months.

Conclusions: Primary esophageal cancer metastasis to penile corpus cavernosum refers to short onset time of metastasis, extensive dissemination, bad response to treatment and poor prognosis. Palliative therapy to patients with the disease could achieve temporary local symptom relief, but not prolong survival time. More research is necessary to understand the underlying mechanism of esophagheal metastasis.
\end{abstract}

Keywords: Penile metastasis, Esophageal carcinoma, Palliative therapy, Case report

\section{Background}

Esophageal cancer is one of the most deadly cancers worldwide, with extremely aggressive nature and 5-year survival of $15-25 \%$, and the main metastatic organs are reported to be liver, lung, bone and brain [1]. Histologic types include squamous carcinoma, adenocarcinoma and undifferentiated carcinoma [2]. Despite the abundant blood supply, penile metastatic cancer, with a poor prognosis of 10-month median survival time, is uncommonly reported no more than 500 cases hitherto [3]. Among these cases, $69 \%$ of penile metastases were primarily from urogenital cancers and 19\% from gastrointestinal caner [4]. Since Gupta NM reported the first case of penile metastasis from esophageal cancer in 1989, only 9 cases were reported worldwide until now [5-13], which were all case reports without systematical study because of the rarity. The present study reports a new case about

\footnotetext{
*Correspondence: dukuar@163.com

'Department of Urology, Ningbo Urology \& Nephrology Hospital, Ningbo

315192, Zhejiang, China

Full list of author information is available at the end of the article
}

the clinical characteristic and management of penile metastases from esophageal cancer. Furthermore, we reviewed all the case reports to provide a summary of the clinical symptoms, treatments, survival and intended to speculate about the possible risk factors, research targets for this disease.

\section{Case presentation}

In September 2017, an 84-year-old male smoker, who had a history of curative resection of esophageal squamous carcinoma (pT3N0M0, phase IIA, moderately differentiated) 12 months before, presented with aggressive dysuria and penis pain for 1 month. He was in good performance status $(E C O G=1)$ with stage 2 hypertension for 30 years, which was under control by regular Nifedipine GITS. His physical examination revealed roughly normal appearance of the penis but several smooth, hard, fixed nodules (diameter from $0.5 \mathrm{~cm}$ to $2.5 \mathrm{~cm}$ ) in the right penile corpus cavernosum, which compressed the penis urethra(Fig. 1a). MRI pelvis protocol scanning confirmed these masses, but did not detect any obvious metastasis in pelvic lymph nodes, bones or 

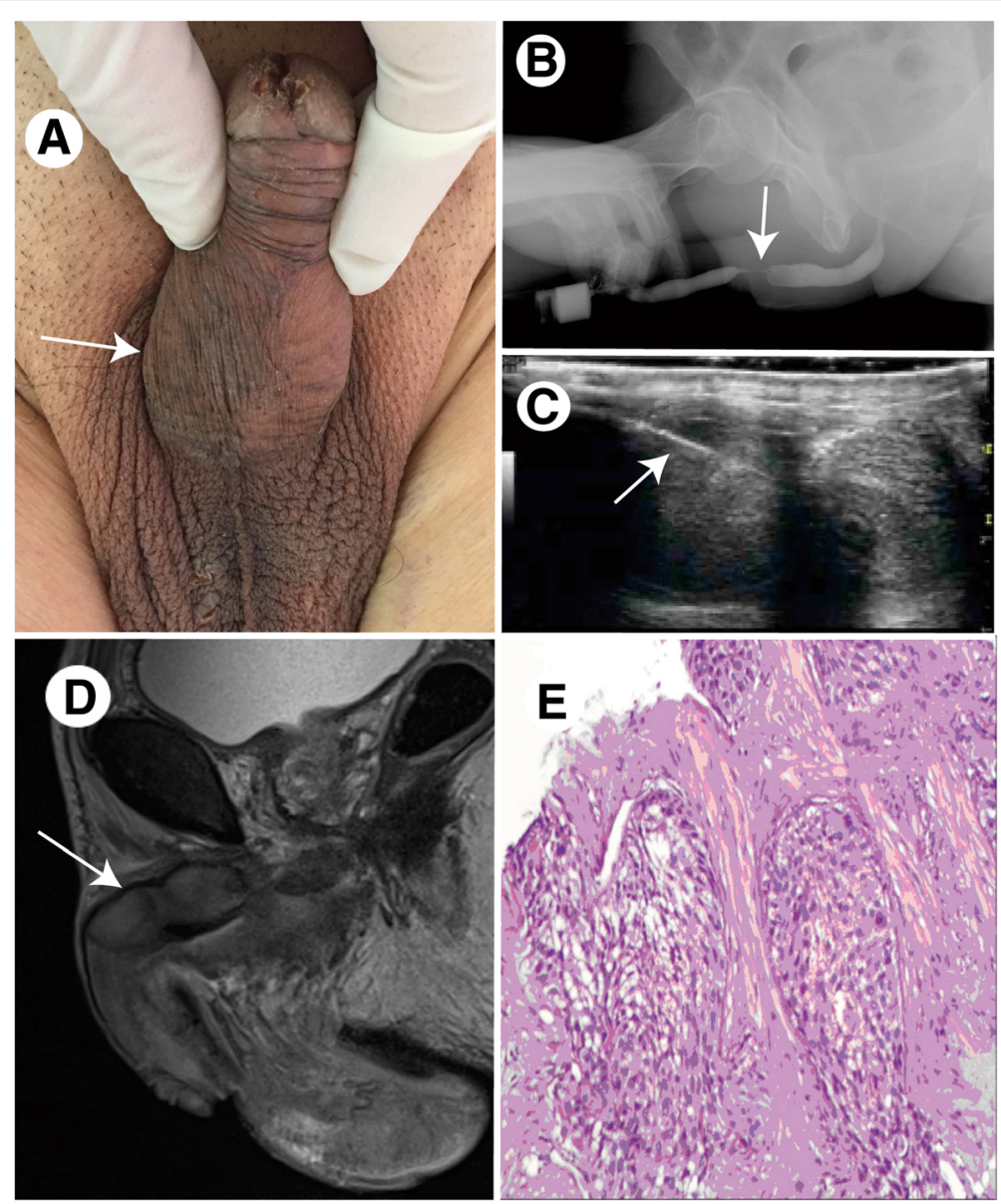

Fig. 1 Urethrostenosis Caused by Metastasis in Penile Corpus Cavernosum from Esophageal Squamous Carcinoma. a: gross appearance of the penis and the palpable hard nodules (arrow); b: retrograde urethrography showed the secondary urethrostenosis (arrow); $\mathbf{c}$ : ultrasonic guided biopsy from one of the nodules, the arrow showed the needle passage of operating biopsy; $\mathbf{d}$ : the mass in the right penile corpus cavernosum confirmed by MRI-T2 weighted phase (arrow); e: pathological diagnosis of the biopsy detected the metastatic squamous carcinoma (HE stain: $\times 40)$

lumber, sacral vetebras,(Fig. 1d). Gastroscopy with biopsy at the anastomosis detected no sign of local recurrence, and there was no radiographic evidence of pulmonary or mediastinal metastases by CT scan. After the failure of urethroscopy, retrograde urethrography showed a $2 \mathrm{~cm}$-length urethrostenosis about $5 \mathrm{~cm}$ proximal to external orifice(Fig. 1b), and he was catheterized (F12, Foley) in case of acute urinary retention. Ultrasonic guided biopsy (Fig. 1c) from one of the nodules diagnosed metastatic squamous carcinoma from the primary in the esophagus(Fig. 1e). IHC revealed positive expression of CK8/18, CK5/6, P40, while negative expression of CK7, CK20. He refused positron emission tomography scan with $\mathrm{CT}$, penectomy or chemotherapy. Then after paracentetic suprapubic cystostomy, we offered him accurately modulated conformal radiotherapy (total radiation absorbed dose: $6000 \mathrm{cGy} / 30$ times) and non-steroidal antiinflammatory drugs (NSAIDs) to alleviate the penis pain. But 4 weeks later, the hard nodules in penile corpus cavernosum progressed; furthermore he developed severe back pain. MRI detected metastasis in the 4th and 5th lumber vertebrae. Since he still rejected further chemotherapy or radiotherapy, we treated him palliatively with paraspinal nerve block and three ladder analgesic programs of cancer to temporarily relieve the pain. After 10 weeks, he presented to us with cough, chest pain and recurrent dysphagia. CT scan revealed pulmonary infection, metastasis in both lungs and suspicious local recurrence in esophagus. $\mathrm{He}$ was discharged when pulmonary infection was cured, and the therapeutic regime turned to hospice care. In January 2018, he died of multiple metastases and cancer cachexia.

\section{Literature review}

We performed a search using PubMed and Chinese National Knowledge Infrastructure (CNKI), which offers medical literature research in China. As mentioned 
above, to the best of our knowledge only 9 cases of penile metastasis from esophageal cancer have been reported from 1989 to 2018. From these 10 cases, including the present and previous reports, we analyzed the clinical feature of the primary (Table 1) and the metastatic cancer (Table 2) in order to get some information for further study about this disease.

The average age was $58.1 \pm 3.8$ years, ranging from 40 to 84 years. Concerning the treatment to primary cancer, curative resection was conducted in 5 cases, partial esophagectomy in 2, chemotherapy and/or radiotherapy in 3. The pathological diagnoses of these primary cancers were exclusively squamous cell carcinoma, of which moderated differentiated account for 50\% (5/10). The TNM stages of the primary cancer were pathological or clinical T3N0M0 to T4N1M1, which indicated the primary cancers were advanced, and metastatic when admitted in 4 cases. The time of penile metastasis since primary cancer diagnosed varied a lot, and the mean time was $9.3 \pm 2.7$ months, ranging from concurrent to more than 24 months. The clinical manifestation included painless $(4 / 10)$ or painful mass $(3 / 10)$, necrosis in glans with pain $(2 / 10)$, dysuria $(4 / 10)$, and priapism(2/ $10)$. The metastatic site could locate in any portion or the full length of penile corpus cavernosum, but none reported in cavernous spongiosum, skin or foreskin. Furthermore, metastases in other organ or lymph node were reported simultaneously in 6 cases. The present case reported the penile metastasis ad the first site and successively metastasis to other organs in 3 months The prognosis was dismal regardless of the methods of treatment to metastases, since the survival time was 5.4 \pm 1.4 months (ranging from 1 month to 12 months).

\section{Discussion and conclusions}

The present report and analysis of literature review reveal that metastasis in penile corpus cavernosum from esophageal squamous carcinoma is a rare disease with a survival time of less than 12 months after diagnosed and poor treatment response. Since this disease is only reported in case reports, there might rarely be reliable evidence from lager data of prospective or retrospective series studied. However, a little more information can be gathered from these cases available. Thereupon, we get conscious of some characteristics of this disease: the primary cancers were exclusively squamous cell carcinoma and local advanced, even metastatic when admitted in a few cases; the metastatic site exclusively located in penile corpus cavernosum, but not in cavernous spongiosum, skin or foreskin; metastasis to other sites simultaneously were detected in most cases, and progressed rapidly with a poor prognosis.

It is widely accepted that the possible mechanisms of metastasis include direct invasion, hematogenous or lymphatic dissemination, iatrogenic spread [3]. Obviously, anatomic proximity is necessary for direct invasion, such as large metastatic mass in the root of penis from the prostate and bladder [14] Penile metastasis from genitourinary system and colon/rectum via pelvic venous plexus and dorsal penile vein was presumed by Abeshouse and Kumer with the evidence of presentation of cancer thrombi in vasculature $[15,16]$. While Paquin proposed

Table 1 Clinical characteristics and treatment of primary cancer

\begin{tabular}{|c|c|c|c|c|c|}
\hline Author & $\begin{array}{l}\text { Age } \\
\text { (year) }\end{array}$ & Primary treatment & Pathology & Stage & Postoperative Therapy \\
\hline Gupta N M & 40 & Radiotherapy & $\begin{array}{l}\text { Poorly differentiated squamous cell } \\
\text { carcinoma }\end{array}$ & $\begin{array}{l}\text { Can't } \\
\text { evaluate }\end{array}$ & - \\
\hline Pai A & 51 & Curative resection & $\begin{array}{l}\text { Moderately differentiated squamous } \\
\text { carcinoma }\end{array}$ & pT3pN1M0 & Adjuvant radiotherapy \\
\hline Zou C & 61 & Curative resection & $\begin{array}{l}\text { Moderately differentiated squamous cell } \\
\text { carcinoma }\end{array}$ & pT3pN1M0 & $\begin{array}{l}\text { Radiotherapy plus } \\
\text { chemotherapy }\end{array}$ \\
\hline Numakura K & 68 & Curative resection & $\begin{array}{l}\text { Poorly differentiated squamous cell } \\
\text { carcinoma }\end{array}$ & pT3pNOMO & - \\
\hline Kobayashi Y & 61 & Curative resection & Well differentiated squamous cell carcinoma & pT3pNOMO & Adjuvant chemotherapy \\
\hline $\begin{array}{l}\text { López-Aramburu } \\
\text { MA }\end{array}$ & 57 & Chemotherapy & Squamous cell carcinoma & CT3NxM1 & - \\
\hline Morán PE & 53 & $\begin{array}{l}\text { Chemotherapy plus } \\
\text { Radiotherapy }\end{array}$ & $\begin{array}{l}\text { Moderately differentiated squamous cell } \\
\text { carcinoma }\end{array}$ & cT4N1M1 & - \\
\hline Li XM & 57 & Lower esophagectomy & Squamous cell carcinoma & $\begin{array}{l}\text { Can't } \\
\text { evaluate }\end{array}$ & - \\
\hline Tang ZJ & 49 & Middle esophagectomy & $\begin{array}{l}\text { Moderately differentiated squamous cell } \\
\text { carcinoma }\end{array}$ & $\begin{array}{l}\text { Can't } \\
\text { evaluate }\end{array}$ & - \\
\hline Song LM & 84 & Curative resection & $\begin{array}{l}\text { Moderately differentiated squamous cell } \\
\text { carcinoma }\end{array}$ & pT3NOMO & - \\
\hline
\end{tabular}


Table 2 Treatment, pathological findings, and follow-up of 9 patients with metastatic penile cancer

\begin{tabular}{|c|c|c|c|c|c|c|c|c|}
\hline Author & $\begin{array}{l}\text { Time of penile } \\
\text { metastasis }\end{array}$ & $\begin{array}{l}\text { Clinical } \\
\text { manifestation }\end{array}$ & $\begin{array}{l}\text { Metastatic } \\
\text { site }\end{array}$ & $\begin{array}{l}\text { Other metastasis } \\
\text { simultaneously }\end{array}$ & $\begin{array}{l}\text { Diagnosis } \\
\text { method }\end{array}$ & Pathology & $\begin{array}{l}\text { Treatment of } \\
\text { metastasis }\end{array}$ & Survival time \\
\hline Gupta NM & 1 week & $\begin{array}{l}\text { Painful } \\
\text { nodules }\end{array}$ & $\begin{array}{l}\text { Dorsal } \\
\text { shaft }\end{array}$ & Not mentioned & $\begin{array}{l}\text { Open } \\
\text { biopsy }\end{array}$ & $\begin{array}{l}\text { Squamous cell } \\
\text { carcinoma }\end{array}$ & $\begin{array}{l}\text { Polydrug } \\
\text { chemotherapy }\end{array}$ & 6 weeks \\
\hline Pai A & 9 months & $\begin{array}{l}\text { Painful } \\
\text { nodules }\end{array}$ & Full length & $\begin{array}{l}\text { Lymph node in left } \\
\text { hilar, subcarinal } \\
\text { and left } \\
\text { supraclavicular }\end{array}$ & $\begin{array}{l}\text { Fine } \\
\text { needle } \\
\text { aspiration }\end{array}$ & $\begin{array}{l}\text { Squamous cell } \\
\text { carcinoma }\end{array}$ & $\begin{array}{l}\text { Palliative } \\
\text { chemotherapy }\end{array}$ & $\begin{array}{l}\text { alive in } 6 \\
\text { months }\end{array}$ \\
\hline Zou C & 6 months & Painless mass & Shaft & $\begin{array}{l}\text { Right thigh; lymph } \\
\text { nodes in left neck }\end{array}$ & $\begin{array}{l}\text { Excisional } \\
\text { biopsy }\end{array}$ & $\begin{array}{l}\text { Moderated } \\
\text { differentiated } \\
\text { squamous cell } \\
\text { carcinoma }\end{array}$ & $\begin{array}{l}\text { Resection of penile } \\
\text { mass; Palliative } \\
\text { external beam } \\
\text { radiation }\end{array}$ & 5 months \\
\hline $\begin{array}{l}\text { Numakura } \\
\mathrm{K}\end{array}$ & $24+$ months & $\begin{array}{l}\text { Dysuria, } \\
\text { Penile pain } \\
\text { Necrosis in } \\
\text { glans }\end{array}$ & Full length & $\begin{array}{l}\text { Brain, liver and } \\
\text { eyes }\end{array}$ & $\begin{array}{l}\text { Excisional } \\
\text { biopsy }\end{array}$ & $\begin{array}{l}\text { Squamous cell } \\
\text { carcinoma }\end{array}$ & $\begin{array}{l}\text { Total penectomy, } \\
\text { chemotherapy }\end{array}$ & 3 months \\
\hline $\begin{array}{l}\text { Kobayashi } \\
\text { Y }\end{array}$ & 2 months & Painless mass & $\begin{array}{l}\text { Glans and } \\
\text { shaft }\end{array}$ & $\begin{array}{l}\text { Abdominal lymph } \\
\text { nodes and spleen }\end{array}$ & $\begin{array}{l}\text { Open } \\
\text { biopsy }\end{array}$ & $\begin{array}{l}\text { Squamous cell } \\
\text { carcinoma }\end{array}$ & Chemotherapy & 5 months \\
\hline $\begin{array}{l}\text { López- } \\
\text { Aramburu } \\
\text { MA }\end{array}$ & $\begin{array}{l}\text { Simultaneously } \\
\text { penile metastasis } \\
\text { was the first } \\
\text { symptom }\end{array}$ & $\begin{array}{l}\text { Pain, } \\
\text { Necrosis in } \\
\text { glans }\end{array}$ & $\begin{array}{l}\text { Glans and } \\
\text { distal shaft }\end{array}$ & Right humerus & $\begin{array}{l}\text { Excisional } \\
\text { biopsy }\end{array}$ & $\begin{array}{l}\text { Squamous cell } \\
\text { carcinoma }\end{array}$ & Partial penectomy & 1 month \\
\hline Morán PE & $24+$ months & $\begin{array}{l}\text { Painless } \\
\text { mass, Dysuria }\end{array}$ & $\begin{array}{l}\text { Glans and } \\
\text { shaft }\end{array}$ & Pelvic lymph node & $\begin{array}{l}\text { Open } \\
\text { biopsy }\end{array}$ & $\begin{array}{l}\text { Squamous cell } \\
\text { carcinoma }\end{array}$ & $\begin{array}{l}\text { Chemotherapy plus } \\
\text { radiotherapy }\end{array}$ & $\begin{array}{l}\text { Withdrawing, } \\
\text { loss to follow } \\
\text { up }\end{array}$ \\
\hline Li XM & 9 months & $\begin{array}{l}\text { Priapism, } \\
\text { Painless } \\
\text { nodle, } \\
\text { Dysuria }\end{array}$ & Shaft & Not mentioned & $\begin{array}{l}\text { Excisional } \\
\text { biopsy }\end{array}$ & $\begin{array}{l}\text { Squamous cell } \\
\text { carcinoma }\end{array}$ & Total penectomy & 10 months \\
\hline Tang ZJ & 4 months & Priapism & Shaft & Not mentioned & $\begin{array}{l}\text { Excisional } \\
\text { biopsy }\end{array}$ & $\begin{array}{l}\text { Moderately } \\
\text { differentiated } \\
\text { squamous cell } \\
\text { carcinoma }\end{array}$ & Total penectomy & $\begin{array}{l}\text { Not } \\
\text { mentioned }\end{array}$ \\
\hline Song LM & 12 months & $\begin{array}{l}\text { Dysuria } \\
\text { Painful } \\
\text { nodules }\end{array}$ & Right shaft & Not detected & $\begin{array}{l}\text { Ultrasonic } \\
\text { guided } \\
\text { biopsy }\end{array}$ & $\begin{array}{l}\text { Moderately } \\
\text { differentiated } \\
\text { squamous cell } \\
\text { carcinoma }\end{array}$ & Radiotherapy & 4 months \\
\hline
\end{tabular}

retrograde lymphatic metastasis to penis might basically locate in the skin, foreskin, because of the abundant lymph supply and widely connection of the penis with pelvic organs via the iliac lymph nodes [14]. Urethra or cavernous spongiosum might be involved by transurethral resection of the prostate or bladder cancer via iatrogenic spread [17]. Because of the anatomical distance, it seems obvious that esophageal cancer does not metastasis via direct invasion, venous or lymphatic dissemination, and iatrogenic spread to the penis. Therefore, we speculate arterial dissemination be the metastatic pathway, which simultaneously indicates the progression and widespread dissemination of the primary cancer.

The treatment, including surgical excision, urinary diversion, radiotherapy, chemotherapy and the combination of these, is usually palliative and relieve local symptom temporarily, but may not delay the progression or prolong survival time. The poor response to treatment lead to the dismal prognosis no more than 6-month's median survival time not only in penile metastasis from esophageal cancer but also from other primary cancers $[3,9]$. However, little is known about the exact mechanism or molecular biology feature of penile metastasis especially from esophageal cancer, which needs to be verified by further research.

Primary esophageal cancer metastasis to penile corpus cavernosum is a rare but fatal condition, which refers to short onset time of metastasis, extensive dissemination, bad response to treatment and poor prognosis. Palliative therapy to patients with the disease could achieve temporary local symptom relief, but not prolong survival time. The rarity of the disease limits clinical study and biochemistry research on it, as well as our understanding of the underlying mechanisms of metastasis for effective treatment and better prognosis. 


\section{Abbreviations}

cGy: Centigray; CK: Cytokeratin; CNKI: Chinese National Knowledge Infrastructure; CT: Computed Tomography; ECOG: Eastern Cooperative Oncology Group; IHC: Immunohistochemistry; MRI: Magnetic Resonance Imaging; NSAIDs: Non-steroidal antiinflammatory drugs

\section{Acknowledgements}

Not applicable.

\section{Funding}

Not applicable.

\section{Availability of data and materials}

All data and material were listed in the present manuscript.

\section{Authors' contributions}

LS and YW cared for the patient. LS and GW wrote this manuscript. We were all responsible for writing and editing the manuscript. All authors have read and approved the final manuscript.

\section{Ethics approval and consent to participate}

This report was approved by Ethnic Committee of Lanzhou General Hospital, $\mathrm{PLA}$, China. The patient' legal representative (his daughter) provided written informed consent.

\section{Consent for publication}

Written consent from the patient's legal representative (his daughter) for publication was obtained.

\section{Competing interests}

The authors declare that they have no competing interests.

\section{Publisher's Note}

Springer Nature remains neutral with regard to jurisdictional claims in published maps and institutional affiliations.

\section{Author details}

${ }^{1}$ Department of Urology, Ningbo Urology \& Nephrology Hospital, Ningbo 315192, Zhejiang, China. ²Department of Urology, Lanzhou General Hospital, PLA, Lanzhou, Gansu, China.

Received: 26 November 2018 Accepted: 6 February 2019

Published online: 20 February 2019

\section{References}

1. Johnson MD, Huang W, Jr WW. Esophageal cancer: risk factors, screening and endoscopictreatment in Western and eastern countries[J]. World Gastroenterol. 2015:21(26):7933.

2. Allen DC. Oesophageal carcinoma[J]. Lancet. 2013;381(9864):400-12.

3. Zhang $\mathrm{K}, \mathrm{Da} \mathrm{J}, \mathrm{Yao} \mathrm{HJ}$, et al. Metastatic tumors of the penis: a report of 8 cases and review of the literature.[J]. Medicine. 2015;94(1):e132.

4. Cocci A, Hakenberg OW, Cai T, et al. Prognosis of men with penile metastasis and malignant priapism: a systematic review[J]. Oncotarget. 2018; 9(2):2923-30.

5. Gupta NM. Penile metastases from esophageal carcinoma[J]. Am J Gastroenterol. 1989;84(3):339-40.

6. Pai A, Sonawane S, Purandare NC, et al. Penile metastasis from esophageal squamous carcinoma after curative resection.[J]. Ann Thorac Cardiovasc Surg. 2008;14(4):238-41.

7. Zou C, Yu D, Qi W, et al. Penile and intramuscular metastases from esophageal squamous cell carcinoma: a rare case report and review of the literature[J]. Can Urol Assoc J. 2014;8(11-12):E875.

8. Numakura K, Tadachi K, Shimoda J. A case of metastatic tumor of penis from esophageal carcinoma.[J]. Hinyokika Kiyo Acta Urologica Japonica. 2008:54(12):795-7.

9. Kobayashi $Y$, Nozawa M, Kikuchi $T$, et al. Penile metastasis from esophageal cancer: a case report.[J]. Hinyokika Kiyo Acta Urologica Japonica. 2013:59(5):315-8.

10. López-Aramburu MA, Viguri DA, Rosa AJ, et al. Penile metastasis like first sign of esophagus carcinoma.[J]. Actas Urologicas Espaolas. 2009; 33(3):318-20.
11. Morán PE, Di CSC, Soto Poveda AM, et al. Penile metastasis of esophageal scamous cell carcinoma[J]. Actas Urologicas Espaolas. 2010;34(3):297-9.

12. Li X. A case report of penile metastatic tumor from esophageal cancer [J] (in Chinese). J New Med. 1996;s1:61-2.

13. Tang Z. A case of metastatic tumor of penis from esophageal cancer [J] (in Chinese). J Clin Urology. 1996:5:304.

14. Paquin AJ Jr, Roland SI. Secondary carcinoma of the penis; a review of the literature and a report of nine new cases. Cancer. 1956;9:626-32.

15. Abeshouse BS, Abeshouse GA. Metastatic tumors of the penis: a review of the literature and a report of two cases. J Urol. 1961;86:99-112.

16. Kumar PP, Newland JR. Metastatic carcinoma of the penis. J Natl Med Assoc 1980;72:55-8.

17. Chaux A, Amin M, Cubilla AL, et al. Metastatic tumors to the penis: a report of 17 cases and review of the literature. Int J Surg Pathol. 2011;19:597-606.
Ready to submit your research? Choose BMC and benefit from:

- fast, convenient online submission

- thorough peer review by experienced researchers in your field

- rapid publication on acceptance

- support for research data, including large and complex data types

- gold Open Access which fosters wider collaboration and increased citations

- maximum visibility for your research: over $100 \mathrm{M}$ website views per year

At BMC, research is always in progress.

Learn more biomedcentral.com/submissions 